\title{
Global hepatitis C elimination: history, evolution, revolutionary changes and barriers to overcome
}

\author{
Carmen Nicoleta OAnCeA ${ }^{1)}$, AnCa Elena Butaru ${ }^{2,3)}$, Costin Teodor Streba ${ }^{4,5}$,

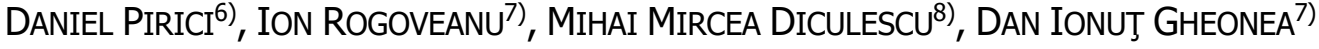 \\ 1) Department of Analytical Chemistry, University of Medicine and Pharmacy of Craiova, Romania \\ 2) PhD Student, Doctoral School, University of Medicine and Pharmacy of Craiova, Romania \\ 3) Department of Infectious Diseases, University of Medicine and Pharmacy of Craiova, Romania \\ 4) Department of Scientific Research Methodology, University of Medicine and Pharmacy of Craiova, \\ Romania \\ 5) Department of Pulmonology, University of Medicine and Pharmacy of Craiova, Romania \\ 6) Department of Histology, University of Medicine and Pharmacy of Craiova, Romania \\ 7)Department of Gastroenterology, University of Medicine and Pharmacy of Craiova, Romania \\ 8) Department of Gastroenterology, Carol Davila University of Medicine and Pharmacy, Bucharest, \\ Romania
}

\begin{abstract}
The fundamental discovery of the hepatitis C virus (HCV) in 1989 has led to winning this year's Nobel Prize in Medicine. This achievement guided all the steps in identifying the elements of the virus, in order to develop the treatment and to increase the screening solutions, which have slowed the exposure to the virus. The management of infection started with interferon-alpha (IFN- $\alpha$ ), which has later enhanced by adding Ribavirin. Nowadays, HCV treatment is based on direct-acting antiviral agents (DAAs). Currently, HCV infection benefits of curative treatment, with which most patients can be cured. When speaking about hepatitis $C$ future, we can say it is looking bright, considering all the progress that has been made in recent years and all the options that we have for curing all genotypes of HCV infection. The aim of this review is to sum up the historical characteristics of HCV discovery, the evolution of treatment and screening actions, gaps, and stages for achieving the international elimination target of the World Health Organization.
\end{abstract}

Keywords: hepatitis $\mathrm{C}$ virus, direct-acting antivirals, genotypes, elimination.

\section{ㅁ Introduction}

This 2020 Nobel Prize in Physiology or Medicine was awarded to Harvey J. Alter, Charles M. Rice and Michael Houghton who have made in 1989 seminal discoveries that led to the identification of hepatitis $\mathrm{C}$ virus (HCV). They had a decisive contribution in the fight against bloodborne hepatitis, a major public health problem, being the source of cirrhosis and liver cancer around the world.

$\mathrm{HCV}$ has been recognized as culprit in the rest of the situations of chronic hepatitis, and it has made possible the creation of new drugs from blood samples that were taken, in order to save millions of lives.

\section{Background: from non-A and non-B hepatitis to hepatitis C}

In 1965, Blumberg et al. discovered the hepatitis B surface antigen (HBsAg), originally known as Australia antigen, at that time it was considered as being the primary cause of serum hepatitis [1]. In order to prevent posttransfusion hepatitis, sensitive tests for HBsAg were developed, thus reducing the number of cases by $50 \%$. However, even though patients received from donors only blood that was HBsAg negative, there still were some hepatitis cases.
The first existence of HCV was fully recognized in 1975, when Feinstone et al. detected hepatitis A virus, while serological tests to identify both hepatitis A and B were in development. It was found that a lot of cases of transfusion-associated hepatitis were not correlating with the two known hepatitis viruses, and so the disease was described as "non-A, non-B hepatitis" (NANBH) [2]. After subsequent transmissions, studies in chimpanzees showed that NANBH was most likely caused by a small-enveloped agent, which progressed to liver cirrhosis that was confirmed in NANBH patients [3]. Hoofnagle et al. started a study in which NANBH was treated with Interferon (IFN)- $\alpha 2 b$. Results showed that the serum aminotransferase levels decreased rapidly on IFN therapy [4]. During the next decade, despite these findings, comprehensive laboratory research was necessary to finally reveal the disease-causing agent.

In 1989, Houghton et al. cloned and sequenced the virus genome and called it HCV [5]. After these discoveries, sensitive tests for $\mathrm{HCV}$ detection were made and the elimination of the virus from the blood transfusion supply was possible.

After the successful depiction of $\mathrm{HCV}$, following analyses divulged that the $\mathrm{HCV}$ genome consists of

This is an open-access article distributed under the terms of a Creative Commons Attribution-NonCommercial-ShareAlike 4.0 International Public License, which permits unrestricted use, adaptation, distribution and reproduction in any medium, non-commercially, provided the new creations are licensed under identical terms as the original work and the original work is properly cited. 
approximately 9600 nucleotides [6, 7]. Translation of the $\mathrm{HCV}$ open reading frame (ORF) produces a polyprotein precursor of 3010 amino acids [8] that is cracked by a combination of viral proteases hosted into 10 different products. Thus, it contains three structural proteins involved with viral particle production (core, E1 and E2) and seven non-structural proteins (NS2 to NS5) that permit viral processing and replication, as well as particle assembly. $\mathrm{HCV}$ was classified as an affiliate of Flaviviridae family, Hepacivirus genus, it also has a related genome organization as Flavivirus, Pestivirus and Pegivirus (GBV-C human virus) [9-13].

$\mathrm{HCV}$ is an enveloped virus, the first indication is the empirical inactivation of $\mathrm{HCV}$ by chloroform, followed by transmission to chimpanzees [9]. It replicates in hepatocytes of infected patients (glycoproteins E1 and E2 help the virus to enter the hepatocyte). Translation and replication were found to be vulnerable on liver-specific micro-ribonucleic acid-122 (miRNA-122) [11, 12]. Since 2011, the use of chimpanzees (the only model that allowed studies of $\mathrm{HCV}$ infection and related instinctive and adaptive host immune responses) has been restricted or even eliminated. Recently, Ploss et al. developed genetically humanized mice with defined HCV replication, which might clear the way for new possibilities of $\mathrm{HCV}$ vaccine for protective immunity [2].

In 1993, phylogenetic analyses demonstrated that HCV could be classified into six genotypes (GTs) with important subtypes [14-16]. Subtypes 1a, 1b, 2a, 2b, 3a, 4a, 5a and $6 \mathrm{a}$ are being studied explicitly, they are well-defined worldwide and by specific population groups [17]. GT1 and GT3 are the most frequent GTs (46\% and respectively $30 \%$ of all HCV cases). GTs 2, 4, 5 and 6 are reported for $9 \%, 8 \%, 1 \%$ and $6 \%$, respectively. GT7 was reported in 2014, and recently GT8 has been found in four patients from India [18]. Today, the exact determination of GT and its subtypes provide us important values about geographical prevalence in different countries and information for targeted anti-HCV treatment. Furthermore, the distribution of GTs and its subtypes has changed over time. The reason would be the elimination of it being transmitted by transfusion, the migration from regions with different GTs distribution and intravenous drug abuse. All these factors have a major role in altering transmission routes [2].

\section{Aim}

The present review article exposes historical aspects of HCV discovery, the evolution of treatment opportunities and the screening strategies. We also discuss what gaps still exist for a global HCV elimination by 2030. It summarizes the future steps that are needed for obtaining our objectives now that the world's attention is being centered on the ongoing severe acute respiratory syndrome coronavirus-2 (SARS-CoV-2) pandemic.

\section{$\neg$ Diagnosis of the HCV infection}

$\mathrm{HCV}$ is considered a hepatotropic virus, which can cause acute and chronic infections and liver damage. HCV approaches the liver cell via the bloodstream, and its infiltration into the cell occurs after adherence to receptors on the surface of host cells being a complex process involving many factors related to both the host and the virus $[19,20]$. The virus multiplies in the liver cell, being released afterwards. Replication occurs with an increased rate of mutations, which is why a single individual can appear different but approximately variants of the same virus. In these cases, the virus circulates as a quasispecies. Innate and adaptive immunity are opposed to this multiplication [21].

After the initial increase in viremia levels, it follows a period of 4-6 weeks of growth, characterized by the absence of HCV-specific T- and B-lymphocytes and the absence of liver inflammation. HCV RNA can be identified in serum in two weeks in almost all patients [22]. Serum transaminases begin to increase later than the second week after exposure, and their levels reach maximum values at 8-12 weeks. Anti-HCV antibodies can occur at different moments, at the time of maximum transaminase growth or after, up to six months after infection. Some patients may never develop antibodies, if the viral clearance occurs before the appearance of HCV antibodies [23]. The clearance of HCV depends on the development of neutralizing antibodies. Acute HCV infection is followed by chronic HCV infection if the immune system cannot eliminate the virus for more than six months after exposure. Chronic viral hepatopathies $\mathrm{C}$ require specific evaluation and monitoring, mainly due to the increased risk of progression to liver cirrhosis and hepatocellular carcinoma [24]. Inflammatory cells of the intrahepatic infiltrate are the main cause of the liver fibrosis $[25,26]$. Age, gender, and race are factors that can determine the progression of fibrosis.

$\mathrm{HCV}$ diagnosis is represented by indirect [anti-HCVimmunoglobulin $\mathrm{M}(\mathrm{IgM})$ for new infections and antiHCV-immunoglobulin G (IgG) for old infections] and direct methods (using virus antigen). Transaminases are used to evaluate the liver. Real-time polymerase chain reaction (PCR) was performed in cases with low viral loads.

\section{Assessment of hepatic fibrosis}

The prognosis and evolution of chronic viral hepatitis is mainly based on the quantification of the degree of hepatic fibrosis, which must be as accessible as possible to the patient, without additional costs and not to require repetition. Although liver biopsy (LB) is considered the reference criterion in the evaluation of liver fibrosis, its invasive nature and low patient acceptability have led to the development of new methods of investigation (Table 1). In the last 10 years, at European level, there has been a decrease in the number of LBs, being preferred noninvasive methods, such as imaging or serology [27]. Their imposition as a first-line diagnostic protocol is also justified by the fact that hepatic fibrosis has a dynamic character, the monitoring of antifibrotic treatment being difficult to perform by liver puncture.

The use of imaging techniques in the diagnosis and evolution of chronic viral liver disease has opened new horizons for assessing the stage of fibrosis, from an incipient fibrosis to the stage of cirrhosis. The broadening of the spectrum of ultrasonography that follows the wellknown characteristics of a cirrhotic liver has allowed the non-invasive evaluation of liver fibrosis by implementing different elastography techniques. Thus, whether quantitative 
or qualitative elastographic techniques were used, the patients benefited from another option in the evaluation of a liver disease.

Table 1 - Advantages and disadvantages of liver biopsy

\begin{tabular}{ll}
\hline \multicolumn{1}{c}{ Liver biopsy } \\
\hline \multicolumn{1}{c}{ Benefits } & \multicolumn{1}{c}{ Disadvantages } \\
\hline Clear diagnostic criteria & Major invasive test \\
\hline Diagnostic value confirmed & Complications include death \\
\hline May suggest the etiology & Significant sampling errors \\
\hline $\begin{array}{l}\text { Can perform differential } \\
\text { diagnosis }\end{array}$ & High cost \\
$\begin{array}{l}\text { Assess the degree and stage } \\
\text { of liver damage }\end{array}$ & Inter-observer variability \\
\hline It can decide the therapy & \\
\hline
\end{tabular}

\section{Liver biopsy}

For the last 50 years, hepatic biopsy has been considered the standard classification criterion for fibrosis [28], as it provides the physician with the necessary information not only on the degree of fibrosis, but also on other processes that take place in the liver, such as necrosis, inflammation, steatosis, or the level of copper and iron deposits [29, 30].
Inflammation (Figure 1), as well as necrosis and accompanying fibrosis (Figure 2) are defining trademarks of liver damage in viral hepatitis. Sometimes, inflammatory infiltrate fills important volumes between liver lobules, thus creating a "spilling" effect over the surrounding hepatocytes (Figure 3). One of the common aspects encountered when analyzing LBs can be cholestasis (Figure 4). Steatosis, both micro- and macrovesicular (Figure 5) also contribute to the altered cytoarchitectonics, with lipid accumulation above $5 \%$ of the total cells. The centrilobular veins are surrounded by altered tissue and exhibit stasis (Figure 6).

All scoring systems greatly rely on sample quality. Since the morphology and integrity of the liver parenchyma is already affected in hepatitis and cirrhosis, it is sometimes difficult to obtain good quality samples. Previous studies established that a minimum of 10 complete portal spaces are needed in a sample, in order to minimize variability and therefore increase the reliability of the interpretation. The histological activity index introduced by Knodell and Ishak was not enough to properly grade disease severity, thus leading the way for the modified variant that was widely accepted.

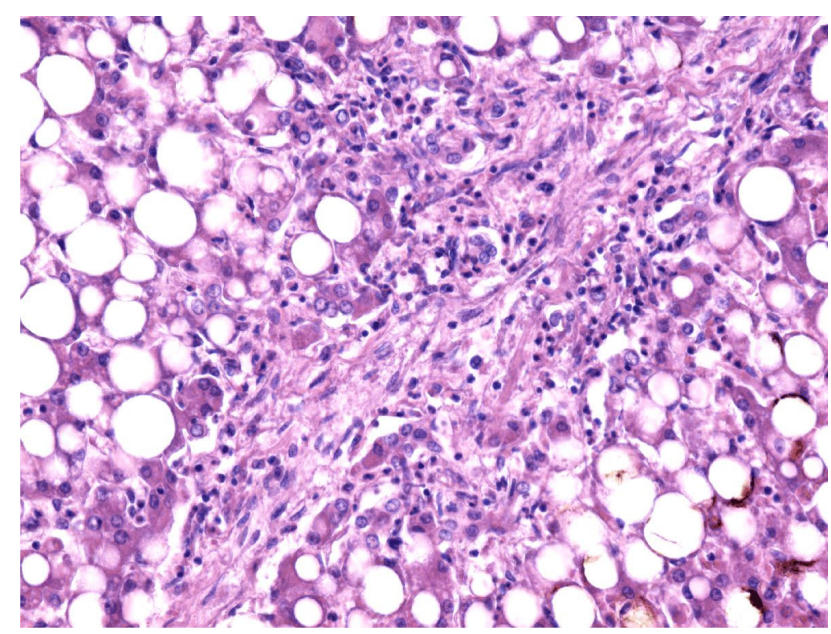

Figure 1 - Pathology image: findings from a biopsy sample of an HCV patient exhibiting fibrosis and chronic inflammation of the liver parenchyma (HE staining, $\times 200)$. HCV: Hepatitis C virus; HE: Hematoxylin-Eosin.

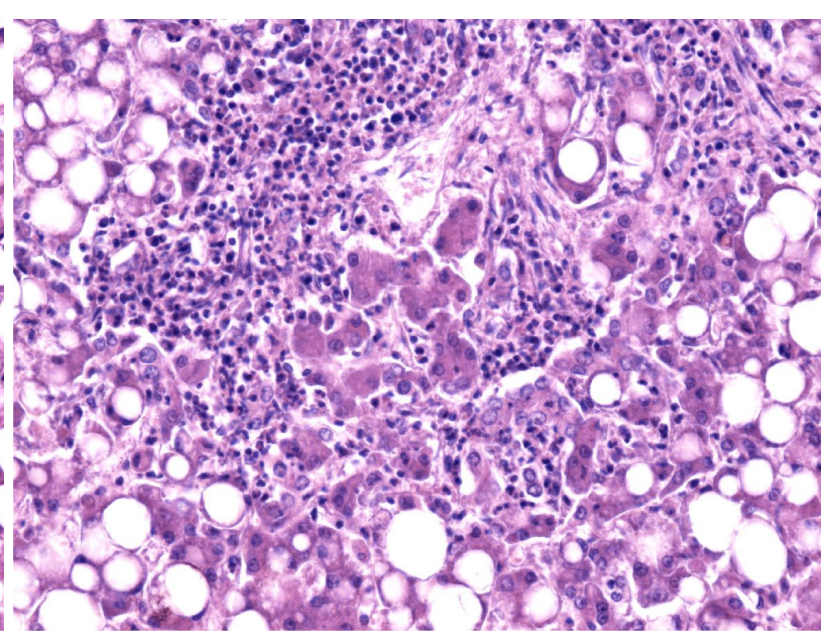

Figure 2 - Necrosis of the parenchyma and inflammatory infiltrate surrounding normal hepatocytes (HE staining, $\times 200)$.

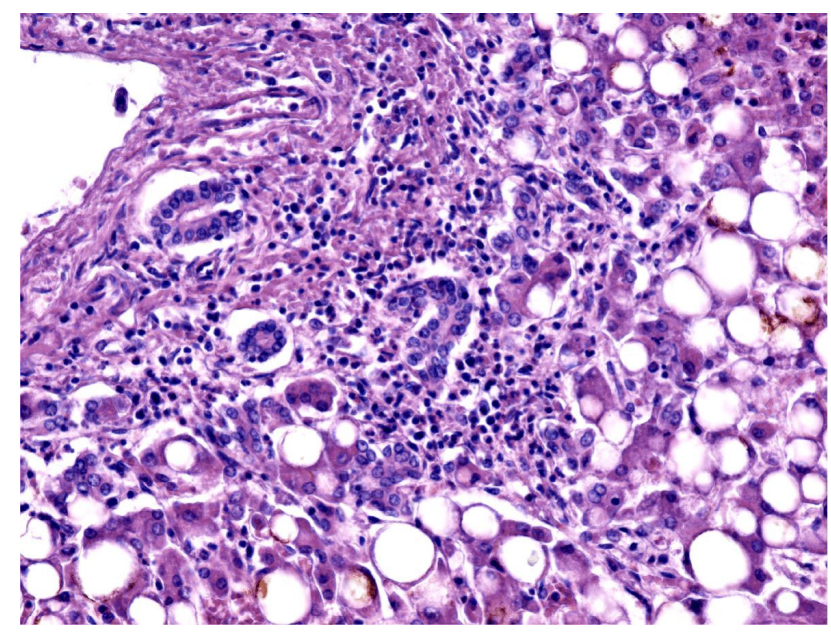

Figure 3 - Lymphocyte spill-over in the intralobular space and between hepatocytes (HE staining, ×200).

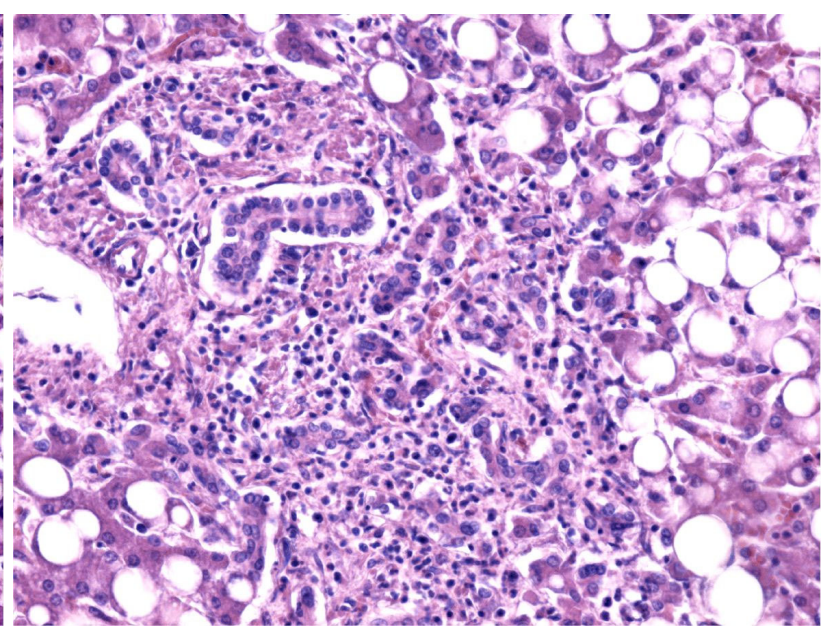

Figure 4 - General aspect of fibrosis, inflammatory infiltrate, canalicular proliferation within the portal spaces and aspects of cholestasis in an HCV patient (HE staining, $\times 100)$. 


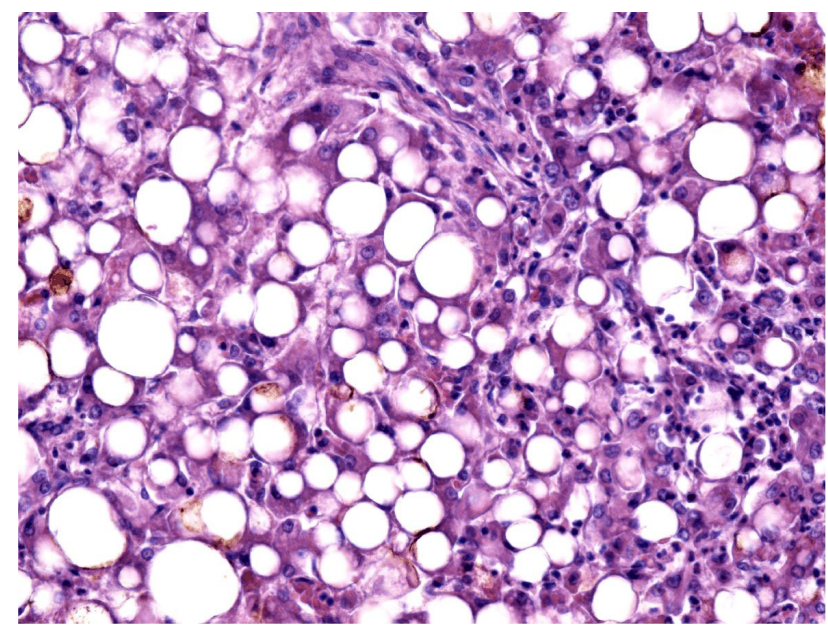

Figure 5 - Micro- and macrovesicular steatosis (HE staining, $\times 200$ ).

Today, Knodell, Ishak, and Metavir scoring systems are the most widely used for LB evaluation [31]. The Ishak score, or revised Knodell system, was initially applied to chronic viral hepatitis B and C. Notably, the initial study published in 1981 included 14 biopsies from five patients, one with hepatitis B and four with NANBH.

The Metavir rating system [32] has been specifically designed to assess liver damage in people infected with the HCV. The Metavir score for hepatitis $\mathrm{C}$ comes with the advantage that it is relatively simple; it is focused on necro-inflammatory lesions but also because it has an increased sensitivity in the degree of evaluation [33].

\section{Imaging methods}

\section{Transient elastography}

Transient elastography (TE) is a non-invasive elastography imaging technique capable of determining the elasticity of liver tissue by generating an elastic wave of $(50 \mathrm{~Hz})$ and an ultrasound (US) wave $(1500 \mathrm{~m} / \mathrm{s})$. The technique has been integrated into a device called Fibroscan (Echosens, Paris, France), which uses a $3.5 \mathrm{~Hz}$ transducer (standard $\mathrm{M}$ probe) that emits consecutive vibrations to record values [34].

Elasticity or hepatic rigidity is measured in the right lobe, by intercostal approach, with the patient positioned in supine position and with the right arm above the head, in maximum abduction. Choose a portion of the liver parenchyma $>6 \mathrm{~cm}$ thick, devoid of vascular structures and the measurement is being made at a depth of 25-65 mm. Make 10 valid measurements $(\mathrm{kPa})$ and calculate their average [26]. The scale ranges from $2.5 \mathrm{kPa}$ to $75 \mathrm{kPa}$. Liver rigidity correlates with the degree of fibrosis, a higher degree of fibrosis leads to greater rigidity. The average in healthy adults is $5.81 \pm 1.54$ and $5.23 \pm 1.59 \mathrm{kPa}$, for men and women, respectively.

TE is a fast, easy-to-perform method with high availability, which can evaluate a sample area often 100 times larger than a biopsy. However, it is difficult to state that the chosen area is without parenchymal changes, which could affect the measurements.

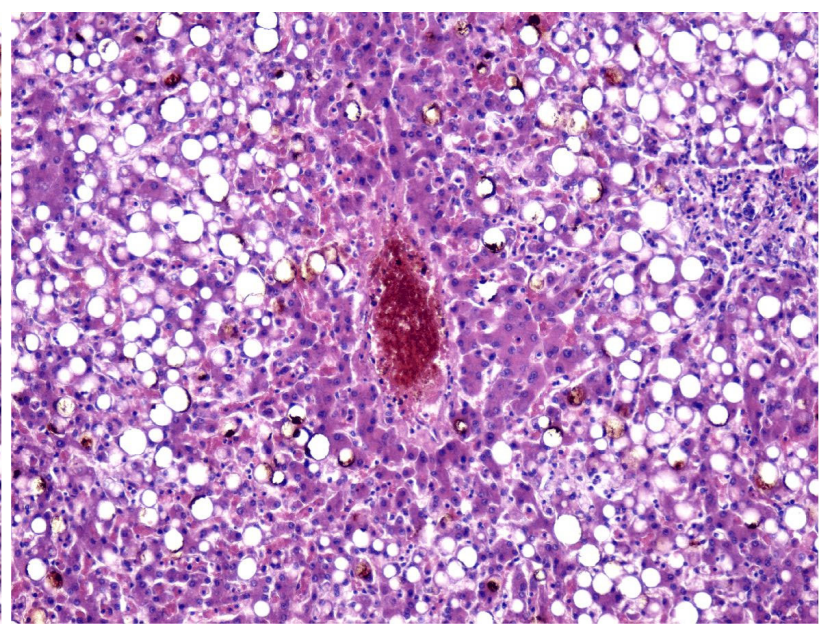

Figure 6 - Centrilobular vein exhibiting intravascular stasis, surrounded by vacuolar degenerescence of the hepatocytes (HE staining, $\times 100)$.

\section{Acoustic radiation force impulse elastography}

Acoustic radiation force impulse (ARFI) elastography is a relatively new elastographic technique that can estimate tissue rigidity by measuring the speed of the shear wave induced by acoustic radiation, a technique that is used with the Siemens Acuson S2000 Virtual Touch ${ }^{\mathrm{TM}}$ US system (Siemens AG, Erlangen, Germany). This technology visualizes both liver tissue but can also quantify liver rigidity. The higher the rigidity of a tissue, the higher the speed. ARFI has the advantage of providing an elastographic measurement of liver rigidity using a conventional ultrasonograph [34].

Similar to TE, scanning is performed through the fifth intercostal space, examining in depth the right hepatic lobe (segment V-VIII), asking the patient to keep the right arm in abduction. Minimal scanning pressure is applied by the operator. The number of measurements required, and which is reported in the literature varies between six and $10[35,36]$.

\section{Real-time elastography}

Real-time elastography (RT-E) is an imaging technique that directly reveals the physical property of tissues using a conventional ultrasonography probe. The principle of this technique is that if an elastic medium is compressed with constant pressure with axial orientation, it produces deformations in the tissue. If one or more constituent elements of the tissue have different rigidity, their deformation will be different [26].

This technique differs from other ultrasonographic techniques in that it does not provide a quantitative estimate of liver rigidity. RT-E measures the induced deformation of the structures examined by the probe, in a conventional US image in B mode, then generating color-coded maps (elastograms) that reflect the elasticity of the tissue [37, 38]. The harder the tissue structure, the bluer the color of the evaluated tissue, and the more elastic the tissues will appear in red.

\section{ElastPQ elastography}

Developed by Philips (Philips Medical Systems, USA), ElastPQ is the latest elastographic method for non-invasive 
evaluation of liver fibrosis based on US, and similar to ARFI elastography, uses the phenomenon of acoustic radiation force impulse.

The ElastPQ system generates an electronic voltage pulse, which is transmitted to the transducer, where the electronic pulse is converted into an ultrasonic pressure wave, which is transmitted through the body's tissues. Doppler mode creates waves in soft tissues and estimates tissue rigidity by determining the speed at which these shear waves pass through region of interest (ROI). Similar to ARFI, ROI has a predefined size, provided by the system (15 mm long and $5 \mathrm{~mm}$ wide). The obtained results are displayed on the screen and the operator can choose in $\mathrm{m} / \mathrm{s}$ or in $\mathrm{kPa}[26]$.

\section{SuperSonic shear imaging elastography}

This technique is integrated into an Aixplorer ${ }^{\mathrm{TM}}$ ultrasonographic system (SuperSonic Imagine S.A., Aix-enProvence, France). The SuperSonic shear imaging (SSI) principle consists in the combination between the induction of "shear waves", their concentration in one place and the ability to capture images at very high speed. In order to capture them in as much detail as possible, very fast frames are needed, of several thousand per second (up to 5000 frames/s). The speed of the shear waves is then estimated by a Doppler system as an acquisition on an area of interest and is used to calculate the rigidity of the tissue using an image in different colors superimposed on the $\mathrm{B}$ mode - in red rigid tissues and in blue - soft tissues [31, 32]. At the same time, a quantitative estimate of liver elasticity is made, its average value in ROI (whose size can be changed by the operator), as well as the standard deviation of the measured elasticity, being displayed on the screen, in $\mathrm{kPa}$, or in if the operator chooses, in $\mathrm{m} / \mathrm{s}$. The advantage of this technique is that the result can be displayed at the same time by the color map, but also by numerical values $[39,40]$.

\section{Magnetic resonance imaging elastography}

In the last decade, significant technological progress has been reported in the development of magnetic resonance imaging (MRI) as a clinical application aimed at using the physiological and biomechanical properties of human liver tissue to detect diffuse or focal pathological conditions, with an excellent correlation of liver elasticity with liver fibrosis [41].

MRI elastography uses a technique based on the phasecontrast sequence that is sensitive to the characteristics of the acoustic wave that occurs in the target organ, and recently this technique has been implemented in assessing the elasticity of several types of tissues [42].

Currently, MRI elastography is considered the most effective method for assessing liver fibrosis. A transducer is placed under the patient's chest to produce images that make up maps of viscosity as well as maps of liver elasticity in a much larger area of interest than other methods [43].

It has several important advantages, including availability in obese and ascites patients. It is not limited by narrow intercostal spaces; it has an increased sensitivity to other elastographic methods in defining average fibrosis and better reproducibility. This technique can be imple- mented in a conventional MRI system by simply adding software and hardware.

\section{Serological methods}

In recent years, there has been a particular interest in the non-invasive assessment of hepatic fibrosis and steatosis. The non-alcoholic fatty liver disease (NAFLD) fibrosis score considers six variables [age, body mass index (BMI), hypertriglyceridemia, platelet count, albumin and aspartate transaminase/alanine transaminase (AST/ALT) ratio] and can be calculated online (www.nafldscore.com). A metaanalysis of 13 published studies totaling 3064 patients [44] identified auspicious values of sensitivity and specificity for the exclusion of advanced fibrosis in patients with NAFLD. Enhanced Liver Fibrosis Panel evaluates the plasma values of three matrix proteins [hyaluronic acid, tissue inhibitor of metalloproteinase-1 (TIMP-1) and procollagen $3 \mathrm{~N}$-terminal peptide (PIIINP)] and has a sensitivity of $80 \%$ and specificity of $90 \%$ in the detection of advanced fibrosis [42, 43]. The quantitative determination of cytokeratin 18 (CK18) fragments in the blood as a predictor of non-alcoholic steatohepatitis (NASH) in patients with NAFLD has also been studied. The presence of CK18 correlates significantly with the NASH elements identified on LB (78\% sensitivity and $87 \%$ specificity) [45-47]. Although all these studies have positive results, the cut-off values are not clearly identified so that they can be used in current practice.

Three blood tests have recently been tested and promoted to estimate fibrosis and its aggravating factors, steatosis, and NASH: SteatoTest, NashTest and FibroTest. FibroMax is the association between these three tests and provides the treating physician with complete information on liver damage [48]. All these algorithms included in FibroMax are patented and belong to the French Public Health Organization (Assistance Publique-Hopitaux de Paris, AP-HP). SteatoTest has values between 0-1, provides an overall assessment of hepatic steatosis regardless of the causative factor (chronic viral hepatitis $\mathrm{C}$, dyslipidemia, diabetes or obesity) and takes into account 10 values of blood biological constants ( $\alpha_{2}$-macroglobulin, haptoglobin, apolipoprotein A1, total bilirubin, gammaglutamyl transpeptidase, ALT, AST, total cholesterol, triglycerides, blood sugar), which they interpret according to age, gender and BMI [49]. The sensitivity and specificity values of the method are satisfactory for a non-invasive assessment of steatosis and are superior to US assessment [50]. The role of NashTest is to identify NASH in patients with NAFLD, to stratify patients with lower or higher liver injury and their risk of developing progressive disease $[48,51]$. The test result can be: NASH certain, NASH possible, without NASH. Given that liver lesions are inhomogeneous, and diagnosis is poorly accurate using LB [52], more and more studies recommend NashTest for screening patients at high risk (obesity, diabetes, hypertriglyceridemia) [53-55]. FibroTest is a universal test, validated to provide a quantitative estimate of fibrosis regardless of etiology and to predict both in the short and long term the evolution of liver disease $[48,56]$. The tests included in FibroMax also have some limitations. They cannot be interpreted in approximately $5 \%$ of patients with acute hemolysis, acute hepatitis, acute inflammation, and extrahepatic cholestasis [57]. 


\section{口 Treatment: early and current options}

The first pharmacological regimen for $\mathrm{HCV}$ was introduced in the final decade of the last century, consisting of $\alpha 2 \mathrm{a}$ or $\alpha 2 \mathrm{~b}$ monotherapy. After two randomized controlled assays (one with two million units IFN- $\alpha 2 b$ versus placebo three times/week for six months and the other with one or three million units IFN- $\alpha 2 b$ versus placebo three times weekly for six months), IFN- $\alpha 2 \mathrm{~b}$ was officially approved for HCV treatment [58-60]. However, high relapse rate, frequent side effects and median sustained virological response (SVR) led to the possibility of another agent. In early 1990s, Ribavirin came as a first attempt to treat chronic hepatitis $\mathrm{C}$ as a monotherapy and it gave immediate results: ALT decreased rapidly, but they rose back to pre-treatment levels after discontinuation of Ribavirin administration [61, 62].

All these studies led to clinical assays where IFN- $\alpha$ was combined with Ribavirin in HCV treatments. Results revealed higher SVR or even complete HCV RNA clearance (the response rates increased to $30 \%$ to $40 \%$ ), such as after multicenter randomized trials on a largescale. In 1999, the combination of IFN- $\alpha$ and Ribavirin was ratified as the accepted treatment of $\mathrm{HCV}$.

Because of the rapid clearance of the IFN- $\alpha 2 b$ drug (difficulties involving administration three times per week) and the heavily dependency on the hepatitis C GT, Pegylated IFN- $\alpha 2 b$ (PegIFN- $\alpha 2 b$ ) was developed as a response. It reduced the frequency of the administration by slowing down the rate in which the drug is absorbed, thus reducing distribution, and decreasing the rate of elimination $[1,19]$. The new combination of PegIFN- $\alpha 2 b$ and Ribavirin has proven to be the principal option of $\mathrm{HCV}$ therapy for the next decade. Recently, studies have shown that a number of side effects were related to IFN therapy: neutropenia, alopecia, hypothyroidism, nausea, flu-like symptoms, vomiting, weight loss, even depression and irritability. In the meantime, better observation of HCV structure, lifecycle and enzymes guided the introduction of new drug purposes.

In 2011, the first direct-acting antiviral agents (DAAs) were discovered and approved for the treatment of $\mathrm{HCV}$ infections. It was a major change that transformed the HCV options in treatment. Telaprevir and Boceprevir (NS3/4A protease inhibitors) were the initial DAAs solutions for HCV [63]. These protease inhibitors were added to the IFN and Ribavirin administrations. Even though they had considerably increased the response rates, they also had significant side effects and were limited to restricted GT activity. In 2013, Sofosbuvir was developed, the first NS5B polymerase inhibitor, which also did not require IFN administration (Figure 7). As it is shown in Figure 8, DAAs products were developed to target the nonstructural coding sequence of $\mathrm{HCV}$. Each product uses a combination of drugs in order to achieve the desired synergistic effect. These once-daily treatments are oral and only needed to be given for eight to 12 weeks, with few side effects and drugs interactions.

The original price for the therapy was around $\$$ 160000 in the beginning. However, as time passed and competition raised, in 2020 the current cost is approximately $\$ 26000$.

Now, with the opportunity of $\mathrm{HCV}$ treatment procedures and a declining cost, the "micro-elimination" approach started to be the focus of the global health strategy on $\mathrm{HCV}$ [63].

\section{a Global HCV elimination in $\mathbf{2 0 3 0}$}

Worldwide, HCV is a major public health concern that in 2015 counted up to 257 million individuals having a chronic hepatitis B virus (HBV) infection. An estimated 71 million of the global population will be chronically infected with HCV and 1.75 million with the new hepatitis $\mathrm{C}$ infection.

In 2016, the World Health Organization (WHO) authorized the Global Health Sector Strategy that ratified the elimination of hepatitis disease by year 2030 [64-66].

The $W H O$ goal for HCV is to reduce its incidence by $90 \%$ and decrease hepatitis C deaths by $65 \%$ by year 2030 [66]. This target was based on increased screening using rapid tests for diagnostic orientation, improving access to $\mathrm{HCV}$ treatment and post-cure follow-up, reinforcing prevention by innovative actions optimized for populations outside the healthcare system and more efficient, highly available and well tolerated therapy is still needed. We have further detailed other factors that prevent the achievement of the $\mathrm{WHO}$ targets (Figure 9).

Improved screening is now critical to reach the $\mathrm{WHO}$ target. Considering that two-thirds of the population with hepatitis $\mathrm{C}$ are not aware of their own infection, the public health strategy can consider the need of focusing on increased screening. The "micro-elimination" concept seems to be still the key in many countries. According to Polaris, Iceland, Switzerland, Australia, Italy, Spain, Mongolia, France, Georgia, Netherlands, Japan, and the United Kingdom diagnosis programs, by sufficient funding and optimal care, are closer to achieve the $W H O$ objectives to eliminate hepatitis. In low-income and middle-income countries, current HBV and HCV treatment rates are low. They are in need of receiving support both financially and politically, from medical and pharmaceutical companies, as well as from civil societies [67].

The target of micro-elimination is to increase the number of patients from disadvantaged groups who get to be tested by the use of rapid diagnostic orientation tests. This implies that individuals who test positive will be immediately offered treatment and subsequent cure. $\mathrm{HCV}$ transmission ends when the elimination goal is achieved. This can only happen when enough people from these disadvantaged groups are cured. This principle was the master plan of the countries mentioned above. They have made impressive developments in reducing the strain of hepatitis $\mathrm{C}$ in their targeted populations by having an extended access to current DAAs treatment.

In these countries, the screening strategy is changing, because they need to pass from micro-elimination to universal screening. They need to include all adults, pregnant women and abandon the risk-based/age-cohort strategy.

The $W H O$ "Global Health Sector Strategy on Viral Hepatitis 2016-2021" target is changing in two new forms of global screening, announced in the spring of 2020. Both United States Preventive Services Task Force (USPSTF) and Centers for Disease Control and Prevention (CDC) expressed their recommendations for $\mathrm{HCV}$ screening for all adults. The USPSTF recommendation is on-time HCV 
screening for all adults with ages between 18 and 79 years. individuals who are aged above 79 years. Pregnant women $C D C$ recommends no upper age limit and includes were also included in their recommendations [63].

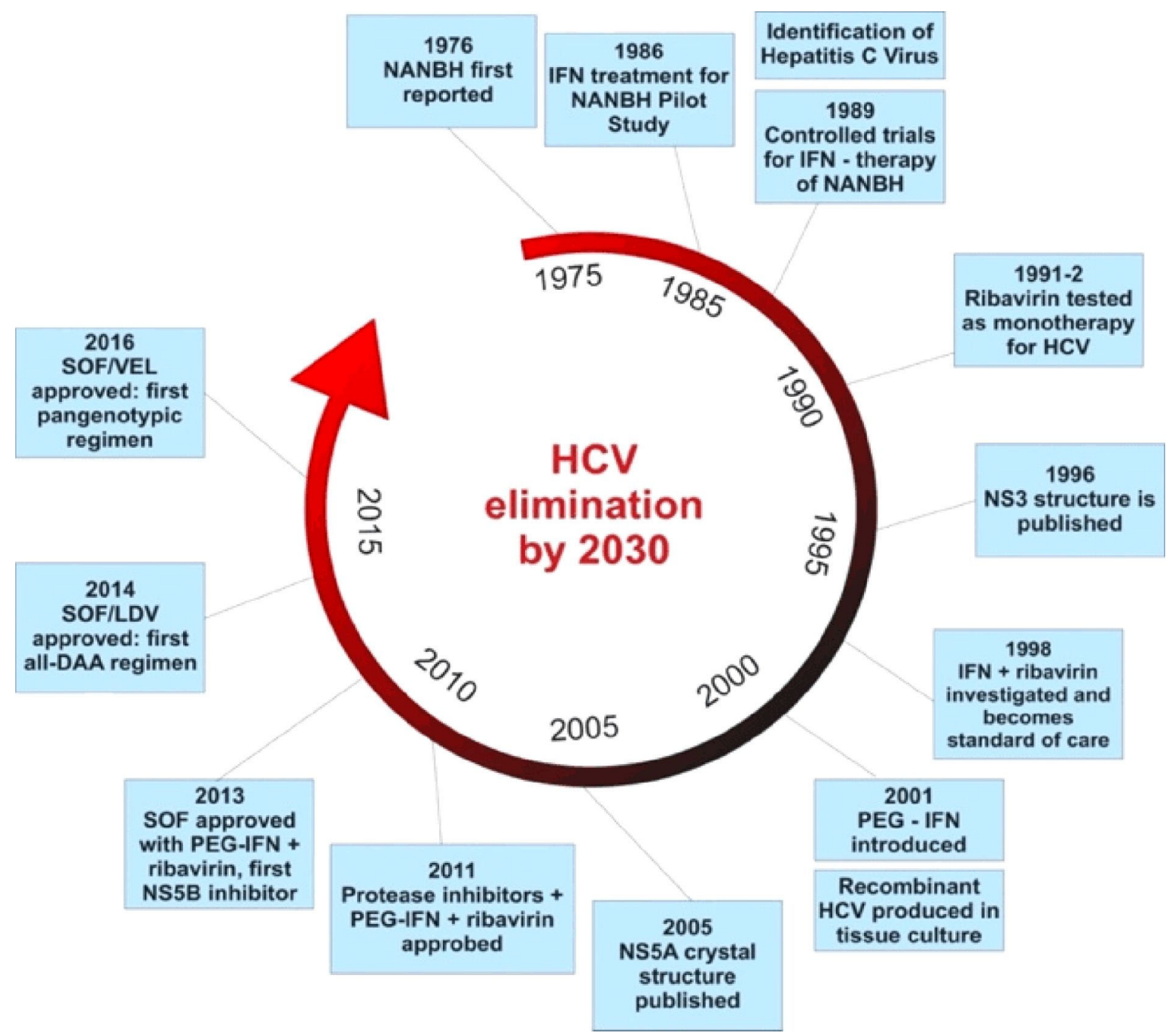

Figure 7 - Early and current options of HCV treatment. DAA: Direct-acting antiviral agent; HCV: Hepatitis C virus; LDV: Ledipasvir; NANBH: Non-A, non-B hepatitis; PEG-IFN: Pegylated Interferon; SOF: Sofosbuvir; VEL: Velpatasvir.

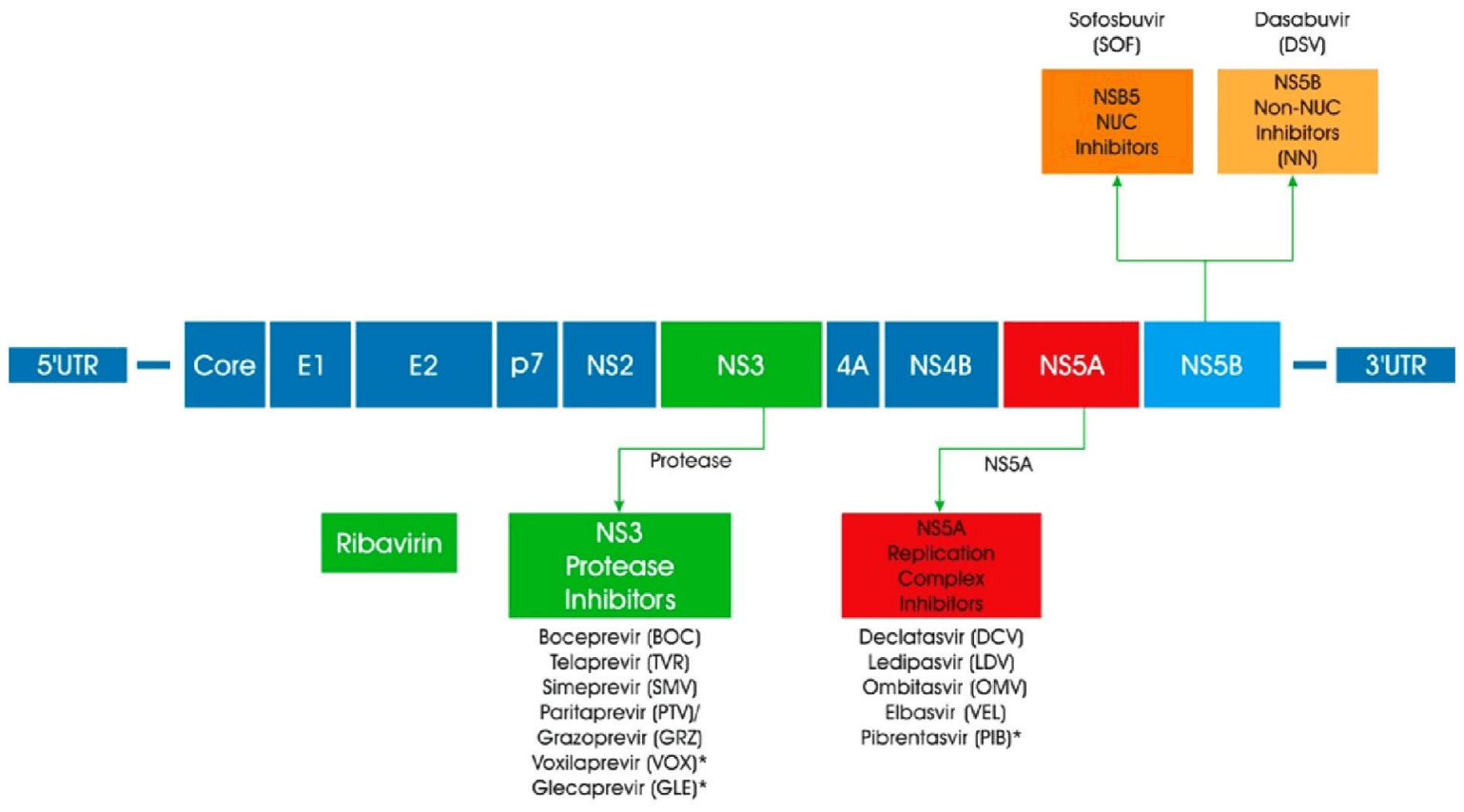

Figure 8 - DAAs used to target products of the nonstructural coding sequence of hepatitis C. DAAs: Direct-acting antiviral agents. 


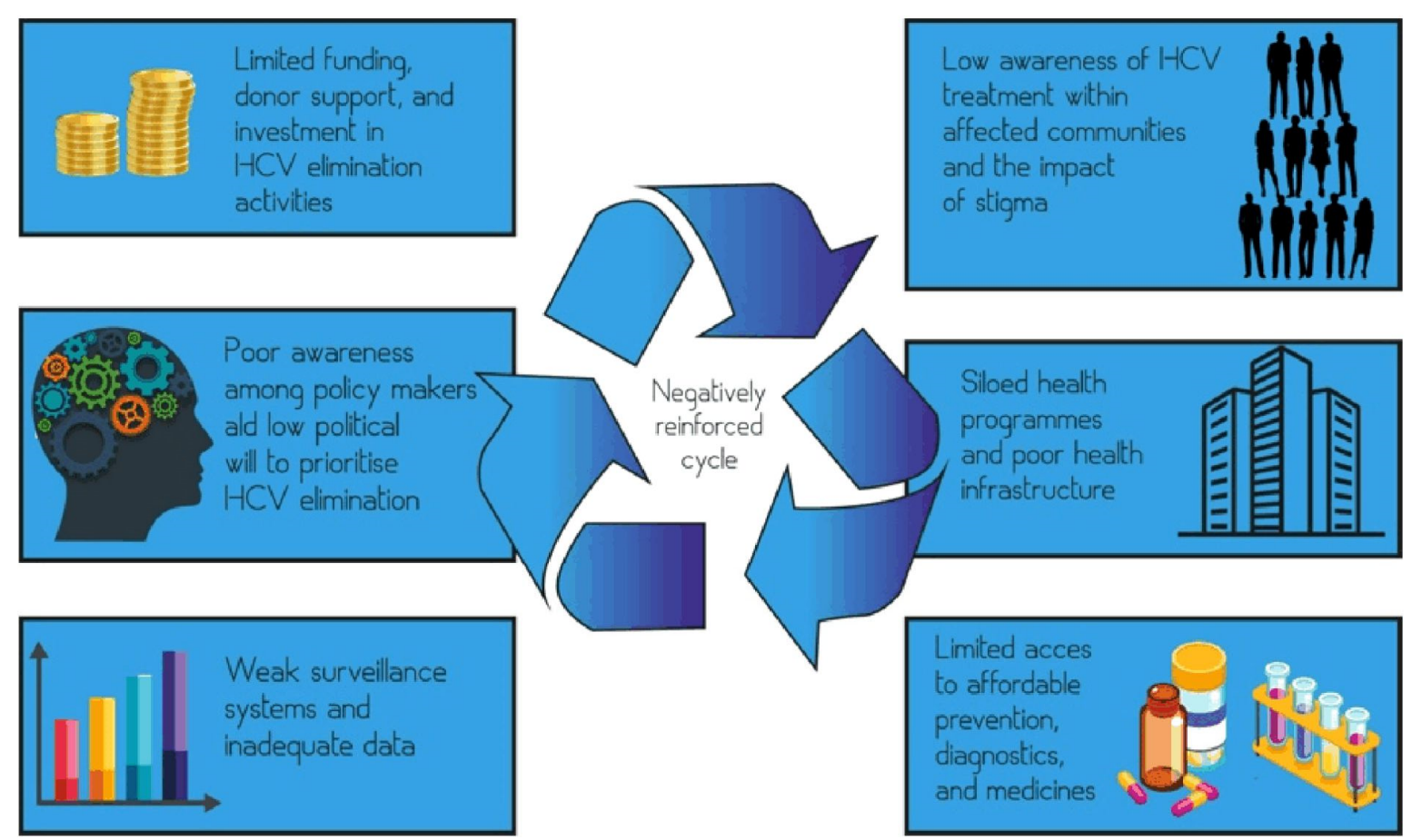

Figure 9 - Factors which prevents the achievement of WHO targets. HCV: Hepatitis C virus; WHO: World Health Organization.

Global screening of all adults is a major step forward compared with the micro-elimination approach, but it may be implemented in countries that have achieved the micro-elimination goal already. For low-income and middle-income countries, the universal screening is not a possibility, due to lower financial resources. In these countries, the first step remains to reach high-risk groups, such as people deprived of liberty, people who inject drugs and people from disadvantaged areas, which have limited access to medical services. All these areas need to implement the micro-elimination plan based on hybrid risk-based/age-cohort strategy.

At this point, the universal screening still has some gaps that must be recognized. There are many studies documenting that injecting drugs increases the chances of developing hepatitis $\mathrm{C}$ before the age of 18 . HCV screening strategy for adolescents has proven to be costeffective. The two pan-genotypic DAAs treatments that are being used now (Glecaprevir-Pibrentasvir and SofosbuvirVelpatasvir) are approved by the United States Food and Drug Administration (FDA) for young individuals from age $12[68,69]$.

Next step would be the screening of adolescents aged 15 to 17 as part of school medical investigations and immediately referred to in case of hepatitis $\mathrm{C}$ treatment, if found to be positive. In addition, HCV screening for infants born to women with hepatitis $\mathrm{C}$ is being discussed in the "Future Directions" section of $C D C$, which is similar with the United States exceptional infrastructure plan to screen and follow-up infants from women with human immunodeficiency (HIV) infection.

The success of both strategies (micro-elimination or universal screening, depending on the current phase in which each country is within the global plan of HCV) resides in offering treatment for those testing positive. The current access to hepatitis $C$ therapies still has gaps in achieving its final goal. Changes in GTs, and the risk of young people up to the age of 18 to be found positive, require a state-of-the-art therapy.

Finally, with increased screening by rapid diagnostic tests and improved access to HCV treatment and postcure follow-up, we remain in need of extra effort and resources for reducing or eliminating the major risks of injectable drugs in $\mathrm{HCV}$ transmission.

In 2020, the impact of SARS-CoV-2 extends significantly on national healthcare systems, with direct damage on the HCV global elimination goal by 2030. Authorities have now to immediately prioritize the national programs of hepatitis because studies have shown that a one-year delay in HCV diagnosis and treatment can add 72300 deaths and 44800 liver cancers from hepatitis C globally by 2030 [70].

\section{a Conclusions}

$\mathrm{HCV}$ infection is a considerable health concern because of the evolution of cirrhosis and relevant complications or hepatocellular carcinoma. Undoubtedly, Alter, Rice, and Houghton's work introduced a new era of virus exploration. This has changed the future of $\mathrm{HCV}$-infected people. In the past, a single blood test has revealed the $\mathrm{HCV}$, which has explained a series of NANBH with negative evolution. Therefore, it became possible to create new drugs that can save people's life. Today, the infection is curable thanks to the revolutionary progress of therapy. This exceptional success by now has served millions of patients all around the world. Better knowledge of the virus throughout the years has contributed to extended treatment alternatives. In the present, DAAs are the standard of care. Extending the treatment accessibility to low and middle-income countries represents the new international objective. Thus, slowing the incidence of HCV by expanding the hepatitis screening programs would also make the elimination possible until 2030. 


\section{Conflict of interests}

The authors declare that they have no conflict of interests.

\section{Authors' contribution}

Carmen Nicoleta Oancea and Anca Elena Butaru contributed equally to this article and share main authorship.

\section{References}

[1] Basyte-Bacevice V, Kupcinskas J. Evolution and revolution of hepatitis $C$ management: from non-A, non-B hepatitis toward global elimination. Dig Dis, 2020, 38(2):137-142. https://doi.org/ 10.1159/000505434 PMID: 31905358

[2] Bukh J. The history of hepatitis C virus (HCV): basic research reveals unique features in phylogeny, evolution and the viral life cycle with new perspectives for epidemic control. J Hepatol, 2016, 65(1 Suppl):S2-S21. https://doi.org/10.1016/j.jhep.2016. 07.035 PMID: 27641985

[3] Alter HJ, Purcell RH, Shih JW, Melpolder JC, Houghton M, Choo QL, Kuo G. Detection of antibody to hepatitis C virus in prospectively followed transfusion recipients with acute and chronic non-A, non-B hepatitis. N Engl J Med, 1989, 321(22):1494-1500. https://doi.org/10.1056/NEJM19891130 3212202 PMID: 2509915

[4] Hoofnagle JH, Mullen KD, Jones DB, Rustgi V, Di Bisceglie A Peters M, Waggoner JG, Park Y, Jones EA. Treatment of chronic non-A, non-B hepatitis with recombinant human alpha interferon. A preliminary report. N Engl J Med, 1986, 315(25): 1575-1578. https://doi.org/10.1056/NEJM198612183152503 PMID: 3097544

[5] Houghton M. Discovery of the hepatitis $C$ virus. Liver Int, 2009, 29(Suppl 1):82-88. https://doi.org/10.1111/j.1478-323 1.2008.01925.x PMID: 19207970

[6] Kato N, Hijikata M, Ootsuyama Y, Nakagawa M, Ohkoshi S, Sugimura T, Shimotohno K. Molecular cloning of the human hepatitis $C$ virus genome from Japanese patients with non- $A$, non-B hepatitis. Proc Natl Acad Sci U S A, 1990, 87(24): 9524-9528. https://doi.org/10.1073/pnas.87.24.9524 PMID: 2175903 PMCID: PMC55204

[7] Choo QL, Richman KH, Han JH, Berger K, Lee C, Dong C, Gallegos C, Coit D, Medina-Selby R, Barr PJ, Weiner AJ, Bradley DW, Kuo G, Houghton M. Genetic organization and diversity of the hepatitis C virus. Proc Natl Acad Sci U S A 1991, 88(6):2451-2455. https://doi.org/10.1073/pnas.88.6.2451 PMID: 1848704 PMCID: PMC51250

[8] Ashfaq UA, Javed T, Rehman S, Nawaz Z, Riazuddin S. An overview of HCV molecular biology, replication and immune responses. Virol J, 2011, 8:161. https://doi.org/10.1186/174 3-422X-8-161 PMID: 21477382 PMCID: PMC3086852

[9] Simmonds P, Becher P, Bukh J, Gould EA, Meyers G, Monath T, Muerhoff S, Pletnev A, Rico-Hesse R, Smith DB, Stapleton JT; ICTV Report Consortium. ICTV virus taxonomy profile: Flaviviridae. J Gen Virol, 2017, 98(1):2-3. https:// doi.org/10.1099/jgv.0.000672 PMID: 28218572 PMCID: PMC 5370391

[10] Wieland S, Makowska Z, Campana B, Calabrese D, Dill MT, Chung J, Chisari FV, Heim MH. Simultaneous detection of hepatitis $C$ virus and interferon stimulated gene expression in infected human liver. Hepatology, 2014, 59(6):2121-2130. https://doi.org/10.1002/hep.26770 PMID: 24122862 PMCID: PMC3975814

[11] Gottwein JM, Bukh J. Cutting the gordian knot-development and biological relevance of hepatitis $\mathrm{C}$ virus cell culture systems. Adv Virus Res, 2008, 71:51-133. https://doi.org/10.1016/S0 065-3527(08)00002-X PMID: 18585527

[12] Jopling CL, Yi M, Lancaster AM, Lemon SM, Sarnow P. Modulation of hepatitis C virus RNA abundance by a liverspecific microRNA. Science, 2005, 309(5740):1577-1581. https://doi.org/10.1126/science.1113329 PMID: 16141076

[13] Stapleton JT, Foung S, Muerhoff AS, Bukh J, Simmonds P. The GB viruses: a review and proposed classification of GBVA, GBV-C (HGV), and GBV-D in genus Pegivirus within the family Flaviviridae. J Gen Virol, 2011, 92(Pt 2):233-246. https:// doi.org/10.1099/vir.0.027490-0 PMID: 21084497 PMCID: PMC3081076
[14] Bukh J, Purcell RH, Miller RH. At least 12 genotypes of hepatitis $C$ virus predicted by sequence analysis of the putative E1 gene of isolates collected worldwide. Proc Natl Acad Sci U S A, 1993, 90(17):8234-8238. https://doi.org/10. 1073/pnas.90.17.8234 PMID: 8396266 PMCID: PMC47323

[15] Bukh J, Miller RH, Purcell RH. Genetic heterogeneity of hepatitis $C$ virus: quasispecies and genotypes. Semin Liver Dis, 1995, 15(1):41-63. https://doi.org/10.1055/s-2007-1007 262 PMID: 7597443

[16] Simmonds P, Holmes EC, Cha TA, Chan SW, McOmish F, Irvine B, Beall E, Yap PL, Kolberg J, Urdea MS. Classification of hepatitis $C$ virus into six major genotypes and a series of subtypes by phylogenetic analysis of the NS-5 region. J Gen Virol, 1993, 74 (Pt 11):2391-2399. https://doi.org/10.1099/ 0022-1317-74-11-2391 PMID: 8245854

[17] Simmonds $P$. The origin of hepatitis $C$ virus. In: Bartenschlager $R$ (ed). Hepatitis $C$ virus: from molecular virology to antiviral therapy. Book Series "Current Topics in Microbiology and Immunology", vol. 369, Springer, Berlin-Heidelberg, 2013, 1-15. https://doi.org/10.1007/978-3-642-27340-7_1

[18] Borgia SM, Hedskog C, Parhy B, Hyland RH, Stamm LM, Brainard DM, Subramanian MG, McHutchison JG, Mo H, Svarovskaia E, Shafran SD. Identification of a novel hepatitis $C$ virus genotype from Punjab, India: expanding classification of hepatitis C virus into 8 genotypes. J Infect Dis, 2018, 218(11):1722-1729. https://doi.org/10.1093/infdis/jiy401 PMID: 29982508

[19] Vere CC, Neagoe D, Streba CT, Prejbeanu I, Ianoşi G, Comănescu V, Pirici D. Steatosis and serum lipid patterns in patients with chronic viral hepatitis: differences related to viral etiology. Rom J Morphol Embryol, 2010, 51(3):509-514. PMID: 20809028

[20] Irshad M, Dhar I. Hepatitis C virus core protein: an update on its molecular biology, cellular functions and clinical implications. Med Princ Pract, 2006, 15(6):405-416. https://doi.org/10.11 59/000095485 PMID: 17047346

[21] Farci P, Alter HJ, Wong D, Miller RH, Shih JW, Jett B, Purcell RH. A long-term study of hepatitis $C$ virus replication in non-A, non-B hepatitis. N Engl J Med, 1991, 325(2):98-104. https:// doi.org/10.1056/NEJM199107113250205 PMID: 1646962

[22] Bertoletti A, Ferrari $\mathrm{C}$. Kinetics of the immune response during HBV and HCV infection. Hepatology, 2003, 38(1):4-13. https:// doi.org/10.1053/jhep.2003.50310 PMID: 12829979

[23] Seeff LB. Strategies for assessing the long-term consequences of hepatitis $C$ virus infection. Minerva Gastroenterol Dietol, 2000, 46(4):207-216. PMID: 16501439

[24] Boldeanu MV, Siloşi I, Bărbulescu AL, Sandu RE, Geormăneanu C, Pădureanu V, Popescu-Drigă MV, Poenariu IS, Siloşi CA, Ungureanu AM, Dijmărescu AL, Boldeanu L. Host immune response in chronic hepatitis $C$ infection: involvement of cytokines and inflammasomes. Rom J Morphol Embryol, 2020, 61(1):33-43. https://doi.org/10.47162/RJME.61.1.04 PMID: 32747893 PMCID: PMC7728117

[25] Lee YA, Wallace MC, Friedman SL. Pathobiology of liver fibrosis: a translational success story. Gut, 2015, 64(5):830-841. https:// doi.org/10.1136/gutjnl-2014-306842 PMID: 25681399 PMCID: PMC4477794

[26] Streba CT, Pirici D, Vere CC, Mogoantă L, Comănescu V, Rogoveanu I. Fractal analysis differentiation of nuclear and vascular patterns in hepatocellular carcinomas and hepatic metastasis. Rom J Morphol Embryol, 2011, 52(3):845-854. PMID: 21892528

[27] Sporea I, Bota S, Săftoiu A, Şirli R, Gradinăru-Taşcău O, Popescu A, Lupşor Platon M, Fierbinteanu-Braticevici C, Gheonea DI, Săndulescu L, Badea R; Romanian Society of Ultrasound in Medicine and Biology. Romanian national guidelines and practical recommendations on liver elastography. Med Ultrason, 2014, 16(2):123-138. https://doi.org/10.11152/ mu.201.3.2066.162.is1sb2 PMID: 24791844

[28] Rockey DC, Caldwell SH, Goodman ZD, Nelson RC, Smith AD; American Association for the Study of Liver Diseases. Liver biopsy. Hepatology, 2009, 49(3):1017-1044. https://doi.org/ 10.1002/hep.22742 PMID: 19243014

[29] Cequera A, García de León Méndez MC. [Biomarkers for liver fibrosis: advances, advantages and disadvantages]. Rev Gastroenterol Mex, 2014, 79(3):187-199. https://doi.org/ 10.1016/j.rgmx.2014.05.003 PMID: 24954541 
[30] Sebastiani G, Alberti A. Non invasive fibrosis biomarkers reduce but not substitute the need for liver biopsy. World $J$ Gastroenterol, 2006, 12(23):3682-3694. https://doi.org/10.37 48/wjg.v12.i23.3682 PMID: 16773685 PMCID: PMC4087461

[31] Knodell RG, Ishak KG, Black WC, Chen TS, Craig R, Kaplowitz N, Kiernan TW, Wollman J. Formulation and application of a numerical scoring system for assessing histological activity in asymptomatic chronic active hepatitis. Hepatology, 1981, 1(5):431-435. https://doi.org/10.1002/hep. 1840010511 PMID: 7308988

[32] Bedossa P, Poynard T. An algorithm for the grading of activity in chronic hepatitis C. The METAVIR Cooperative Study Group. Hepatology, 1996, 24(2):289-293. https://doi.org/10.1002/hep. 510240201 PMID: 8690394

[33] Popescu NL, Predescu OI, Badea O, Pirici I, Pantiş C, Busuioc CJ, Cotoi BV, Mogoantă L. The process of liver fibrosis in chronic hepatitis C - histological and immunohistochemical study. Rom J Morphol Embryol, 2018, 59(4): 1121-1126. PMID: 30845293

[34] Bamber J, Cosgrove D, Dietrich CF, Fromageau J, Bojunga J, Calliada F, Cantisani V, Correas JM, D'Onofrio M, Drakonaki EE, Fink M, Friedrich-Rust M, Gilja OH, Havre RF, Jenssen C Klauser AS, Ohlinger R, Saftoiu A, Schaefer F, Sporea I, Piscaglia $F$. EFSUMB guidelines and recommendations on the clinical use of ultrasound elastography. Part 1: Basic principles and technology. Ultraschall Med, 2013, 34(2):169_ 184. https://doi.org/10.1055/s-0033-1335205 PMID: 23558397

[35] Sporea I, Sirli RL, Deleanu A, Popescu A, Focsa M, Danila M Tudora A. Acoustic radiation force impulse elastography as compared to transient elastography and liver biopsy in patients with chronic hepatopathies. Ultraschall Med, 2011, 32(Suppl 1):S46-S52. https://doi.org/10.1055/s-0029-1245360 PMID: 20603783

[36] Karlas T, Pfrepper C, Wiegand J, Wittekind C, Neuschulz M, Mössner J, Berg T, Tröltzsch M, Keim V. Acoustic radiation force impulse imaging (ARFI) for non-invasive detection of liver fibrosis: examination standards and evaluation of interlobe differences in healthy subjects and chronic liver disease. Scand J Gastroenterol, 2011, 46(12):1458-1467. https://doi.org/ 10.3109/00365521.2011.610004 PMID: 21916815

[37] Gheonea DI, Săftoiu A, Ciurea T, Gorunescu F, lordache S, Popescu GL, Belciug S, Gorunescu M, Săndulescu L. Realtime sono-elastography in the diagnosis of diffuse liver diseases. World J Gastroenterol, 2010, 16(14):1720-1726. https://doi.org/10.3748/wjg.v16.i14.1720 PMID: 20380003 PMCID: PMC2852819

[38] Shin J, Yoon H, Cha YJ, Han K, Lee MJ, Kim MJ, Shin HJ. Liver stiffness and perfusion changes for hepatic sinusoidal obstruction syndrome in rabbit model. World J Gastroenterol, 2020, 26(7):706-716. https://doi.org/10.3748/wjg.v26.i7.706 PMID: 32116418 PMCID: PMC7039830

[39] Bercoff J, Tanter M, Fink M. Supersonic shear imaging: a new technique for soft tissue elasticity mapping. IEEE Trans Ultrason Ferroelectr Freq Control, 2004, 51(4):396-409. https://doi.org/10.1109/tuffc.2004.1295425 PMID: 15139541

[40] Muller M, Gennisson JL, Deffieux T, Tanter M, Fink M. Quantitative viscoelasticity mapping of human liver using supersonic shear imaging: preliminary in vivo feasibility study. Ultrasound Med Biol, 2009, 35(2):219-229. https://doi.org/ 10.1016/j.ultrasmedbio.2008.08.018 PMID: 19081665

[41] Talwalkar JA, Yin M, Fidler JL, Sanderson SO, Kamath PS Ehman RL. Magnetic resonance imaging of hepatic fibrosis: emerging clinical applications. Hepatology, 2008, 47(1):332342. https://doi.org/10.1002/hep.21972 PMID: 18161879

[42] Naganawa S, Kawai H, Fukatsu H, Sakurai Y, Aoki I, Miura S, Mimura T, Kanazawa $\mathrm{H}$, Ishigaki T. Diffusion-weighted imaging of the liver: technical challenges and prospects for the future. Magn Reson Med Sci, 2005, 4(4):175-186. https://doi.org/ 10.2463/mrms.4.175 PMID: 16543702

[43] Huwart L, Peeters F, Sinkus R, Annet L, Salameh N, ter Beek LC, Horsmans Y, Van Beers BE. Liver fibrosis: noninvasive assessment with MR elastography. NMR Biomed, 2006, 19(2):173-179. https://doi.org/10.1002/nbm.1030 PMID: 16521091

[44] Vuppalanchi R, Gould RJ, Wilson LA, Unalp-Arida A, Cummings OW, Chalasani N, Kowdley KV; Nonalcoholic Steatohepatitis Clinical Research Network (NASH CRN). Clinical significance of serum autoantibodies in patients with NAFLD: results from the nonalcoholic steatohepatitis clinical research network. Hepatol Int, 2012, 6(1):379-385. https:// doi.org/10.1007/s12072-011-9277-8 PMID: 21557024 PMCID: PMC3511661

[45] Musso G, Gambino R, Cassader M, Pagano G. Meta-analysis: natural history of non-alcoholic fatty liver disease (NAFLD) and diagnostic accuracy of non-invasive tests for liver disease severity. Ann Med, 2011, 43(8):617-649. https://doi.org/10. 3109/07853890.2010.518623 PMID: 21039302

[46] Wieckowska A, Zein NN, Yerian LM, Lopez AR, McCullough AJ, Feldstein $\mathrm{AE}$. In vivo assessment of liver cell apoptosis as a novel biomarker of disease severity in nonalcoholic fatty liver disease. Hepatology, 2006, 44(1):27-33. https://doi.org/10. 1002/hep.21223 PMID: 16799979

[47] Angulo P, Hui JM, Marchesini G, Bugianesi E, George J, Farrell GC, Enders F, Saksena S, Burt AD, Bida JP, Lindor K, Sanderson SO, Lenzi M, Adams LA, Kench J, Therneau TM, Day CP. The NAFLD fibrosis score: a noninvasive system that identifies liver fibrosis in patients with NAFLD. Hepatology, 2007, 45(4):846-854. https://doi.org/10.1002/hep.21496 PMID: 17393509

[48] Wieckowska A, McCullough AJ, Feldstein AE. Noninvasive diagnosis and monitoring of nonalcoholic steatohepatitis: present and future. Hepatology, 2007, 46(2):582-589. https:// doi.org/10.1002/hep.21768 PMID: 17661414

[49] Munteanu M, Ratziu V, Morra R, Messous D, Imbert-Bismut F, Poynard T. Noninvasive biomarkers for the screening of fibrosis, steatosis and steatohepatitis in patients with metabolic risk factors: FibroTest-FibroMax experience. J Gastrointestin Liver Dis, 2008, 17(2):187-191. PMID: 18568141

[50] Poynard T, Ratziu V, Naveau S, Thabut D, Charlotte F, Messous D, Capron D, Abella A, Massard J, Ngo Y, Munteanu M, Mercadier A, Manns M, Albrecht J. The diagnostic value of biomarkers (SteatoTest) for the prediction of liver steatosis. Comp Hepatol, 2005, 4:10. https://doi.org/10.1186/ 1476-5926-4-10 PMID: 16375767 PMCID: PMC1327680

[51] Yao W, Zhao B, Zhao Y, Wang W, Qian G. Ultrasonographic texture analysis of parenchymatous organs by the fourneighborhood-pixels algorithm: clinical experiment. J Ultrasound Med, 2001, 20(5):465-471. https://doi.org/10.7863/jum. 2001.20.5.465 PMID: 11345103

[52] Poynard T, Ratziu V, Charlotte F, Messous D, Munteanu M, Imbert-Bismut $\mathrm{F}$, Massard J, Bonyhay L, Tahiri M, Thabut D, Cadranel JF, Le Bail B, de Ledinghen V; LIDO Study Group; CYTOL Study Group. Diagnostic value of biochemical markers (NashTest) for the prediction of non alcoholo steato hepatitis in patients with non-alcoholic fatty liver disease. BMC Gastroenterol, 2006, 6:34. https://doi.org/10.1186/1471-230X-6-34 PMID: 17096854 PMCID: PMC1657015

[53] Ratziu V, Charlotte F, Heurtier A, Gombert S, Giral P, Bruckert E, Grimaldi A, Capron F, Poynard T; LIDO Study Group. Sampling variability of liver biopsy in nonalcoholic fatty liver disease. Gastroenterology, 2005, 128(7):1898-1906. https://doi.org/10.1053/j.gastro.2005.03.084 PMID: 15940625

[54] Ratziu V, Giral P, Munteanu M, Messous D, Mercadier A, Bernard M, Morra R, Imbert-Bismut F, Bruckert E, Poynard T. Screening for liver disease using non-invasive biomarkers (FibroTest, SteatoTest and NashTest) in patients with hyperlipidaemia. Aliment Pharmacol Ther, 2007, 25(2):207-218. https://doi.org/10.1111/j.1365-2036.2006.03182.x PMID: 17229244

[55] Băloşeanu CL, Streba CT, Vere CC, Comănescu V, Rogoveanu I. Association between liver histology, carotid ultrasonography and retinal vascular changes in patients with nonalcoholic fatty liver disease (NAFLD). Rom J Morphol Embryol, 2012, 53(3):609-614. PMID: 22990555

[56] Streba LAM, Cârstea D, Mitrut P, Vere CC, Dragomir N Streba CT. Nonalcoholic fatty liver disease and metabolic syndrome: a concise review. Rom J Morphol Embryol, 2008, 49(1):13-20. PMID: 18273497

[57] Ngo Y, Munteanu M, Messous D, Charlotte F, Imbert-Bismut F, Thabut D, Lebray P, Thibault V, Benhamou Y, Moussalli J, Ratziu V, Poynard T. A prospective analysis of the prognostic value of biomarkers (FibroTest) in patients with chronic hepatitis C. Clin Chem, 2006, 52(10):1887-1896. https:// doi.org/10.1373/clinchem.2006.070961 PMID: 16931569

[58] Vere CC, Streba CT, Streba L, Rogoveanu I. Statins in the treatment of hepatitis C. Hepat Mon, 2012, 12(6):369-371. https://doi.org/10.5812/hepatmon.5998 PMID: 22879825 PMCID: PMC3412552 
[59] Di Bisceglie AM, Martin P, Kassianides C, Lisker-Melman M, Murray L, Waggoner J, Goodman Z, Banks SM, Hoofnagle JH. Recombinant interferon alfa therapy for chronic hepatitis $\mathrm{C}$. A randomized, double-blind, placebo-controlled trial. N Engl J Med, 1989, 321(22):1506-1510. https://doi.org/10.1056/ NEJM198911303212204 PMID: 2509917

[60] Davis GL, Balart LA, Schiff ER, Lindsay K, Bodenheimer HC Jr, Perrillo RP, Carey W, Jacobson IM, Payne J, Dienstag JL; Hepatitis Interventional Therapy Group. Treatment of chronic hepatitis $\mathrm{C}$ with recombinant interferon alfa. A multicenter randomized, controlled trial. N Engl J Med, 1989, 321(22) 1501-1506. https://doi.org/10.1056/NEJM198911303212203 PMID: 2509916

[61] Reichard O, Andersson J, Schvarcz R, Weiland O. Ribavirin treatment for chronic hepatitis C. Lancet, 1991, 337(8749): 1058-1061. https://doi.org/10.1016/0140-6736(91)91707-2 PMID: 1673493

[62] Di Bisceglie AM, Shindo M, Fong TL, Fried MW, Swain MG, Bergasa NV, Axiotis CA, Waggoner JG, Park Y, Hoofnagle JH. A pilot study of ribavirin therapy for chronic hepatitis $\mathrm{C}$. Hepatology. 1992, 16(3):649-654. https://doi.org/10.1002/hep 1840160307 PMID: 1505907

[63] Jhaveri R. Screening for hepatitis $C$ virus: how universal is universal? Clin Ther, 2020, 42(8):1434-1441. https://doi.org/ 10.1016/j.clinthera.2020.06.012 PMID: 32712026 PMCID: PMC7376340

[64] World Health Organization (WHO). Global hepatitis report, 2017. WHO Press, Geneva, 2017. https://apps.who.int/iris/ handle/10665/255016

[65] United Nations General Assembly. Transforming our world: the 2030 Agenda for Sustainable Development. Resolution adopted by the General Assembly on 25 September 2015, A/RES/70/1 (21 October 2015). https://www.refworld.org/docid/ 57b6e3e44.html

[66] WHO. Global health sector strategy on viral hepatitis 20162021. Towards ending viral hepatitis. WHO Press, Geneva June 2016 (WHO/HIV/2016.06). https://apps.who.int/iris/handle/ $10665 / 246177$

[67] Polaris Observatory. Countries on track to eliminate HCV by 2030. Center for Disease Analysis Foundation (CDAF), Polaris Observatory, 2017, accessed: September 2020. http://cda found.org/polaris/

[68] Jonas MM, Squires RH, Rhee SM, Lin CW, Bessho K Feiterna-Sperling C, Hierro L, Kelly D, Ling SC, Strokova T, Del Valle-Segarra A, Lovell S, Liu W, Ng TI, Porcalla A, Gonzalez YS, Burroughs M, Sokal E. Pharmacokinetics, safety, and efficacy of Glecaprevir/Pibrentasvir in adolescents with chronic hepatitis $C$ virus: Part 1 of the DORA Study. Hepatology, 2020, 71(2):456-462. https://doi.org/10.1002/hep.30840 PMID: 31254392 PMCID: PMC7028097

[69] Nguyen J, Barritt AS 4th, Jhaveri R. Cost effectiveness of early treatment with direct-acting antiviral therapy in adolescent patients with hepatitis C virus infection. J Pediatr, 2019, 207: 90-96. https://doi.org/10.1016/j.jpeds.2018.12.012 PMID: 30738661

[70] Blach S, Kondili LA, Aghemo A, Cai Z, Dugan E, Estes C, Gamkrelidze I, Ma S, Pawlotsky JM, Razavi-Shearer D, Razavi H, Waked I, Zeuzem S, Craxi A. Impact of COVID-19 on global HCV elimination efforts. J Hepatol, 2021, 74(1):3136. https://doi.org/10.1016/j.jhep.2020.07.042 PMID: 32777322 PMCID: PMC7411379

\section{Corresponding author}

Costin Teodor Streba, Associate Professor, MD, PhD, Department of Scientific Research Methodology and

Department of Pulmonology, University of Medicine and Pharmacy of Craiova, 2 Petru Rareş Street, 200349 Craiova, Romania; Phone +40722-389 906, e-mail: costin.streba@umfcv.ro

Received: December 10, 2020

Accepted: March 25, 2021 